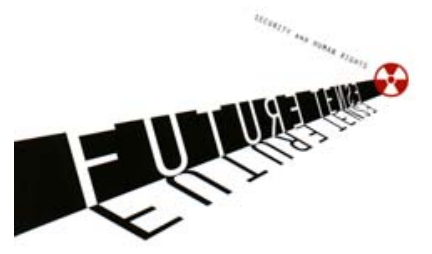

\title{
SECURITY AND HUMAN RIGHTS
}

\author{
Caroline Turner
}

'Fear - otherwise styled security'. Salvador de Madariaga (1886-1978), 'Morning without Noon', 1974.

This exhibition takes as its two key points of reference contemporary global concerns about security and contemporary global concerns about human rights.

Both are emerging as crucial to defining our lives and our future in the 21st Century.

Artists can give a special insight into these concerns and in the process highlight our common humanity. And Art, as French artist Christian Boltanski has reminded us, 'is always a witness, sometimes a witness to events before they actually occur...'

'Fear - otherwise styled security', in the words of Spanish historian, diplomat and head of disarmament at the League of Nations in the 1920s, Salvador de Madariaga, ${ }^{2}$ has become the prevailing note of the opening years of the 21st Century. Our world in our present is obsessed with security and a 'war on terror'. If this period comes to be identified in history as the Age of Terror, it will be terror in a particular sense. This is terror which targets civilians and non-combatants, as most recently in London and in Bali and in Israel and in New York and in Egypt and ... where next?

It is also a time of extraordinary challenge to the principles of human rights which 57 years ago were enshrined in a 'Universal' Declaration adopted by the United Nations in 1948 in the hope of securing a better future for all the peoples of the world. The tragic fact is, however, that hopes for a culturally tolerant, humane and secure future remain unfulfilled in our time. As a leading scholar of international law, Professor Christine Chinkin, noted in 2003, poverty, war, imprisonment, torture, genocide and other abuses remain: 'The universality of human rights standards is challenged as abuses are committed in the name of religion, custom and tradition and increasingly in this post 11 September 2001 environment, national security ....'

Terror can, of course, come from the top down as well as from the bottom up, and on a far vaster and more destructive scale, because a State customarily has far greater capacity for destruction to hand than those seeking to oppose it. There is also the inherent problem that measures taken by a State to defend itself against terror can have the effect of eroding the values which the State itself claims to defend. War is frequently about terror and war is inevitably about absolute distinctions of right and wrong - our side and the enemy. But it is rarely in human relations as simple as absolute right and wrong. War cannot be an end in itself and at some point there needs 
to be a basis for peace. One person's terrorist can be another's freedom fighter; but the complexities do not stop there: it is a situation in which those under threat can come too easily to resemble those who are seen as constituting a threat. As Pat Hoffie reminds us in her essay in this catalogue, the enemy can be within us. The atmosphere of fear and suspicion can also exacerbate differences and mistrust between peoples and escalate fear, violence and terror. Fear drives the quest for security, and it is the most basic psychological truth that one can come to resemble what one most fears. It is the dilemma which Graham Greene posed seventeen years ago in the epigraph to his novel 'The Captain and the Enemy'.

It is precisely the enigmatic aspect of 'security' that infuses the works of the artists in this exhibition. The eight artists included each take a very different approach to the complex historical and other factors encompassed in the concept of security. In doing so they help us to address the even more complex issue of human rights in the context of security in the present.

It would be difficult for an artist to be more adept than Gordon Bennett in conveying the enigmatic nature of this nightmare dilemma. Bennett's concept of Australia's identity as a nation clearly includes, in the words of Simon Wright, 'terror both as a historical component of Australian colonisation and contemporary existence'. His 'Camouflage' painting of Saddam Hussein deliberately blurs 'the line between oppressor and oppressed - between colonisers and colonised, between the "here" and "there" ', leaving it 'open to negotiation and renegotiation, summarised as the postcolonial condition...."
It immediately raises the question, Who is Saddam? Is he the friend of the West who invaded Iran and massacred his own people? Or the enemy who invaded Kuwait? Or the enemy whom the West invaded, ostensibly for not revealing weapons of mass destruction which it now appears he did not possess, and for theoretically supporting al-Qaeda, who would have been his own worst enemies until we came along? And some now claim that Iraq was invaded for humanitarian reasons to liberate and give freedom to its people - some of whom Australia rejected as refugees when they fled the regime. And is not 'camouflage' an appropriate symbol for this war?

In the $9 / 11$ series Bennett recreates the terror of attack but the faces of fear have been echoed in his reconstructions of Australian Indigenous history of a decade earlier. Despite hysterical and inaccurate statements by some media that $9 / 11$ is the first time US Americans have been attacked on their home soil, Bennett is not alone in perceiving the much greater complexity underlying such an assumption about history. In a speech in Canberra, Australia in 2002, Dr Richard West, Director of the National Museum of the American Indian in Washington stated, in answer to a question from the audience, that Native Americans have much to teach their fellow Americans about being attacked in one's own country. Washington and New York have also been the sites of much historical bloodshed besides - Native American wars, wars by colonisers against the Native American first nations, colonial wars for a continent, the Seven Years War and other conflicts, including the British against French, the American Revolutionary war against the British, Loyalists against Revolutionaries, the war of 
1812 when the British burned Washington, and the terribly bloody American Civil War, as well as potential and actual slave revolts, ethnic, race and other riots and civic violence. And of course within living memory the attack on Pearl Harbor in Hawaii. And, as distinguished historian David Cannadine noted in a recent seminar at the $\mathrm{HRC}$ in Canberra, recognition of the existence of an historical American empire and all that that entails in the present is something not readily faced by Americans.

Bennett's work reminds us of another critical theme of

this exhibition: history and the ambiguities surrounding our often selective remembering of the past.

Eminent British historian of empire Linda Colley, currently an HRC Visiting Fellow, was recently quoted on Aljazeerah Arab website from her earlier analysis of Tony Blair's statement in relation to the war in Iraq that 'History will forgive us' ${ }^{5}$ But as Colley pointed out, Blair, and all of us are 'constrained by, and entangled in, history'. British imperial occupiers last century in Iraq experienced the same sort of problems, she wrote, as US [and British and Australian] troops face today. For Blair '...the past is irrelevant, because this is a new world facing entirely new dangers' (Globalization and WMD). The artists in this exhibition remind us, however, that the past is not only with us with all its unanswered questions but is in reality shaping a future which looks frighteningly like the past. And a new century, the 21st, is coming more and more to look like a new version of the 20th, - the bloodiest in the experience of the human race.

Dadang Christanto, whose previous work has memorialised victims of violence in every time and place, in his 'Count Project', begun in 1999 set out to count those killed by violence in the 20th and 21st centuries.

Dadang started the project in December 1999, when the world was 'celebrating the ...third millennium'. He felt with reason 'worried about what has happened in the 20th century. In the past century there have been massacres everywhere, bloodshed everywhere. Violence just to make people suffer'. And the fact was that 'we have always failed to stop violence, instead we have more violence. September 11, 2001, the War in Afghanistan, the Bali bombing and the War in Iraq' all were 'actual global evidence that violence is becoming the solution to problems. This is a strong sign that we are living in the barbarian age'. He had accordingly been 'counting the number of victims of violence'. ${ }^{6}$ As a small boy this artist experienced his own personal nightmare of violence: in 1965 when he was eight years old his father 'disappeared', taken away by soldiers. The five children were unaware their father had gone. He has never been heard of since, being presumably one of the estimated hundreds of thousands of people (estimates vary up to 2 million) who were murdered between September 1965 and May 1966 for alleged or imagined Communist sympathies. The horror was compounded by the total element of the mysterious - the dead have never been numbered, the graves have never been found, the bodies have never been returned and nobody has ever been held responsible. Historian Robert Cribb has concluded that while the number killed may be closer to half a million, the event is 'the greatest tragedy in modern Indonesian history'. ' These arrests and mysterious killings were prompted by fear and undertaken in the name of security in that those who 'disappeared' were supposed to 
be threats to security. And a number of the victims, such as Dadang's father, Tan Ek Tjioe, were of Chinese descent and small business men. Chinese were natural targets, for exactly the same reasons as Jews were in Europe: for their different ethnicity, different religion and real or supposed prosperity. In his performance as part of this exhibition, 'Litsus', Dadang Christanto recalls (as he has only been able to recall since he moved to Australia) the stigma attached to the families of those who disappeared, their lack of security, the fact they could never publicly speak of the dead or disappeared and of the complicity of all in that silence as the audience is made complicit during the performance. Either by standing by or by actively participating in violence.

In 'Litsus' the audience must either stand by or participate in the violence by throwing missiles at Dadang (or in the first performance of this work also at his young son Gunung who was the same age, eight years old, as Dadang was when his father disappeared). In the second part of this performance, seen on video in this exhibition 'Searching displaces bones' we see a wrapped body removed and carried forward, slowly unwrapped and subjected to forensic investigation as in an archaeological excavation, inspired, the artist has said, by seeing the bodies of those massacred at Srebrenica (BosniaHerzegovina) in 1995 carried out from the excavations of mass graves. This event is considered to be one of the largest mass murders in Europe since World War II with estimates of up to 8,000 Muslim Bosnians murdered at that place. Surely in his imagination must also be the thought that one day his own father's body may be similarly found. And in the minds of the audience who watched this performance in Australia must have been the thought could Australia ever witness such scenes? But Dadang Christanto's work is not concerned with the political nature of violence but with what makes us human. Inhumanity, injustice, insecurity, fear, oppression and the suffering of humankind are always there to be confronted; and these are the enemies he confronts in his art. His art is not to be confined to any specific ideology, religion or locality, as is demonstrated again and again by the fact that it resonates with viewers who have no notion of any political content or background, although one obviously can appreciate the significance of many of them more fully if one does have some knowledge of the background. But the fact is that audiences respond to his works as art but also in terms of their own experience of human tragedy.

Another war, and another child. Like Christanto who was a child in Indonesia in 1965, Tran Luong was a child in Vietnam in the early 1970s. He explores his personal memories of fleeing the US bombing of Hanoi in what is called in Vietnam 'the American war'. He drew on this life journey and his love of nature as well as his Buddhist beliefs in making the video 'Flowing' which he calls his 'self explanation for growing-up, observing, absorbing and accepting, based on the positive philosophy I learnt from Buddhism'. Tran Luong has stated that hate was not something he took with him from the experience of war into his adult life and 'my feeling always [was to separate]... Americans and [the] American regime..$^{8}$

Like Guan Wei who as a youth was sent to the countryside during the cultural revolution to be re-educated, Tran Luong learned much from nature and his life in rural areas and from 
the kindness of those who looked after the refugees fleeing bombing. Communism triumphed in Vietnam thirty years ago, after great sacrifices, including the deaths of two million of its people. The French and the Americans both were defeated. Yet the new free market economy in a time of peace also brought concerns of the potential loss of culture and history from globalisation, of the violent and even horrific massproduced toys from the West that fill his son's world, replacing the gentle toys of wood and paper that delighted a previous generation, and of the street kids in Vietnam who have no toys and nowhere to go. Peace has certainly brought greater security from the horror of being killed or maimed by American bombs or strafed by napalm but not necessarily security of livelihood or home in a globalised world dominated by wealthy nations where the gulf between haves and have nots grows ever wider.

John Pule whose work is also about survival is the archetypal Pacific artist: As Simon Wright points out, Nicholas Thomas has referred to a 'Pacific signature', despite Pule's apparent rejection of some significant Polynesian practices including Christianity brought by missionaries and his claim only to represent himself and the history of his own family. He was born in the tiny village of Liku in the tiny island of Niue (pop. ca.2000).Pule emigrated to New Zealand at the age of two. He is a virtually self-taught, poet, novelist, printmaker and New Zealand Laureate Artist 2004, with an oeuvre deploying an extraordinary variety of media, fusing 'cosmology, cartography, biography and corporality $^{\prime 10}$ It is a remarkable record of personal achievement, mirroring the remarkable collective achievement of Pacific culture, of which Torres Strait Islander Tom
Mosby said that its survival refuted the theory of evolution, in that it manifested the weak overcoming the strong, appropriating and adapting for their own purposes the technology, material and techniques of the world outside. But the fact is that the culture of the Pacific peoples is still engaged in a desperate struggle for survival. Colonisation and globalisation are the natural targets of Pacific artists, especially one like Pule, whose work is such a brilliant elucidation of the family stories of so many islanders. Pule is an artist of extraordinary strength, whose terrifying images in the works in this exhibition foreshadow and predict more such tragedies to come. This strength is displayed with what can only be described as combined rage and despair in the 'American Series' shown in this exhibition. The works exhibited here are etchings on paper, horrifying images of victimisation in its most appalling forms of mutilation and mutation. They passionately denounce the arrogance of power and the subjection of the human, echoing Dadang Christanto's words that 'Human beings are not objects'."

There could hardly be a greater contrast with the stark fury and violence of John Pule's etchings than the meticulously delicate and intricate miniatures of Pakistani artist Saira Wasim, painted with brushes made from the tail hairs of a kitten or a baby squirrel and derived from the rich tradition of miniature painting on the Sub continent and with inspiration from Mughal courts and the theatre. But the fact is that, in the words of Anna Sloan, these delicate miniatures presenting 'the devastating truths behind the celebratory veneers and fear mongering of the post-9/11 world', with portraits of 'gluttonous power brokers, weak-willed political pawns', and 'hard-edged terrorists, bear a 
humanist mark, as if violence, hubris, and greed were signs of deep human frailty. In the artist's own soft-spoken words, her work sets forth a "humble plea" for social and political reform'.

As the artist herself says 'I believe from centuries ... weak remains weak and strong suppress weak and emperors play with the wishes of their people'. $\quad$ Nor has any artist placed their own security at greater risk in memorialising the insecurity of others, in her case particularly the truly desperate insecurity of Pakistani women, vulnerable to the arbitrary and unpunished terror of 'honour killings'. But it is clear that it is not fear but rather her strength that inspires her to paint.

\section{Australian artist eX de Medici} explores the complex psychology of security, of fear and of death in her drawings in this exhibition, which echo the themes of her artistic oeuvre: installation, performance, drawing, photography and tattooing. The extraordinary delicacy and scientific precision of the drawings imbue violence with a strange and surreal beauty as she explores the fascination of our society with guns and violence. They are also a 'memento mori' and thus a reminder that we all must die and can be seen to echo the fantastical, visionary quality of Medieval and Renaissance graphic art in an era of particular fear and anxiety about death, survival and the afterlife. They have an affinity in subject matter and execution with the graphic art of artists such as Albrecht Dürer who employed images from the popular culture of another turn of a century age - the last decades of the fifteenth and first decades of the sixteenth centuries. Dürer combined this popular imagery with what Vasari called his own 'extravagant imagination' and the exquisite precision of his execution in his graphic work which came to embody the iconography and ideas of a whole society and ultimately its deep insecurity in a time when humanism and religious faith were both facing momentous internal and external threats: the Muslim Turks were at the gates of Belgrade, and the split between Catholics and Protestants would soon lead to the terror of violent religious and civil war.

The insecurity of our times at the turn of our century and in a new millennium is central to Guan Wei's work in this exhibition. As an immigrant Australian brought up with different perspectives on history (he recalls as a child the stand off between China and Taiwan and also the Cultural Revolution), Guan Wei explores secret or forgotten histories and raises crucial questions of fear and security in our times. Some of his most recent works dealt with Australia's rejection of refugees and boat people attempting to come to this country. Guan Wei continues to employ a certain patina of humour, with his trademark of the little pink figures that he has adopted since coming to Australia. But the little pink figures can suffer and drown as they attempt to escape from whatever desperate situation they leave behind them, only to be repelled from suddenly inhospitable shores. Guan Wei's painting on the subject and his theme of the history of human migrations in every time and place seem to echo the words of Chilean artist Alfredo Jaar who has said in relation to the deaths on the US Mexican border: 'It is an unacceptable tragedy that in the 21st century people still die trying to simply cross a border between two countries'.

Guan Wei created the new series in this exhibition, cryptically entitled 'Looking for the enemy', after a 
residency in New York, a city absorbed with the aftermath of attack and the imagery of the 'war on terror'. In this powerful new series of paintings invading fleets pollute the Pacific, even if it is open to question who is invading whom. In the two paintings in this exhibition we see Australia being invaded, or possibly rescued, by armed forces, and the 19th century bushranger and folk hero Ned Kelly is defying his pursuers. The bushrangers and very bourgeois settlers along with emus, kangaroos and a 19th century image of Aborigines are together in a landscape where a helicopter is disgorging more armed invaders/rescuers, festooned across a barren terrain with incongruous place names like 'Mt Relief' and 'Bay of Plenty' and even, most remarkably, 'Demigod'. But who is doing the invading? Or who the rescuing? Are they Ours or Theirs? And who would They be, anyway? And who was Ned Kelly, apart of course from being the ultimate Australian iconic figure, along with the archetypal 'digger'? Outlaw or defender of human justice? Irish patriot or cop killer? Robin Hood or just plain robbing villain? Or all of these, as may very well have been the case? Are the Indigenous people the ones being invaded or the white settlers? And are the settlers and the bushrangers in confrontation or collusion or just being iconically Australian, like the soldiers disembarking from the helicopter? Who indeed and what is 'the enemy' in this binary - the oppositional juxtaposing of fear and security?

Wong Hoy Cheong adds a further dimension to the enigma by reversing brilliantly the colonial gaze with his pseudo-documentary 'RE-Looking', merging real and imaginary histories, with the theme of the establishment of a mythical Malaysian/'Melakan' empire and the consequences of its decolonisation upon some of its former Austrian subjects, who have come to live in Malaysia in hope of enjoying a better standard of living than offered to them in their former homeland, presumably crippled economically and socially by the experience of being colonised, as has indeed been the usual experience of victims of European colonisation. Their better life entails working as cleaners and taxi drivers, but things would be even worse for them at home, where streets still bear names in Malay and are adorned with crossed krises. The account records the founding of the empire by a 17th century 'Melakan' sultan Iskander Shah, who follows up a series of military triumphs by seeking a world empire ${ }^{15}$, in the manner of his namesake Alexander. Eastward is naturally the path of empire for him too, the global shape of the planet ensuring that Europe is east of Asia just as Asia is east of Europe. His invasion fleets go round the Horn and link up with the Ottoman Turks to accomplish the conquest of Hapsburg Empire. Nor is there anything intrinsically absurd in the concept of European peoples being colonised by Asians: most of Southeast Europe was under the rule of the Ottoman Empire for nearly 400 years, and most of Russia accepted the authority of the Golden Horde for over 200 years. Vienna was in fact besieged by the Turks in 1529 and again in 1683. The fact that it has usually been Asians and Africans rather than Europeans who have been on the receiving end of colonialism, is merely a transient phenomenon of a particular time in human history. The video is presented as a production by the imaginary Malaysian Broadcasting Commission, with the conventional paraphernalia of historical maps, 'newsreels' cunningly giving the appearance of old film about to disintegrate, and commentaries by a Malaysian 
'authority', suitably understanding and sympathetic to the conditions of the immigrants, and by an Austrian, marvellously serious, reflective and judicious in the best manner of Teutonic scholarship. The charming and sophisticated young Malaysian presenter in Wong Hoy Cheong's video maintains the relentlessly insinuating and complacent know-all style of his profession (seen on television screens around the world), except for certain surreal interludes when he eats what appears to be dirt.

Wong Hoy Cheong's work is another reminder that artists can confront us with the deep ambiguities in our views of the world, how colonisers and colonised are equally changed by the process, and how our views are shaped by the victors. Guan Wei has analysed 'mediated information flows' as Laura Murray Cree points out $^{16}$ and Bennett's 'Camouflage' series the way our vision is mediated by camouflaged distorted modes of representation. News broadcasts every evening on television deny connections which might seem obvious such as the link between the London bombings and the war in Iraq. The charming young Malaysian commentator in 'RE-Looking' provides a view of the world which is simple and straight forward and totally assured of its own validity. It is a fantasy world but where is the fantasy and where the reality? Once again who is the enemy? The message from Wong Hoy Cheong is that anybody can be colonised and anybody can be a coloniser. Or in Dadang Christanto's terms, anyone can be a victim and anyone an oppressor.

Safeguarding Australia's security should necessitate in the first issue an understanding of the nature of cultures which have come to be regarded in some quarters at least as potentially threatening to this country. This is especially the case when such cultures are strongly represented in our own country. In the last issue the greatest security for any nation should be the sense among its citizens that this is a nation committed to tolerance, respect and human rights. But such sentiments are all too easily overtaken by fear and suspicion of our fellow citizens (the other within) and of those 'others' outside our borders we have defined as our enemies and come to fear. And perhaps the greatest fear of all: to come to resemble what one most fears. Art is not produced in a vacuum: it responds to the sociopolitical climate of its times. Goya to the Napoleonic invasion of Spain. Picasso to the horrors of the civil war in his country of birth; the Dadaists and German Expressionists to the overwhelming chaos, disillusionment and baffled rage of post-World War I Europe; post Second World War artists to the exigencies of Cold War confrontation. Artists today respond to the pervading sense of insecurity and consequent concern for security that

has compromised the euphoria of the dawn of a new millennium.

Anxiety is multiplied by uncertainty. The artists represented in this exhibition, from Australia, the Pacific, Vietnam, Malaysia, China, Indonesia and Pakistan convey with their wholly diverse insights the prevailing malaise: the mood of present anxiety and future tense.

Caroline Turner

Deputy Director of the Humanities

Research Centre

The Australian National University 
Notes:

Research for this project has been supported by an ARC Research Council Discovery grant 'The Limits of Tolerance in the 21st Century' and by research support from the Australian Research Council's Asia Pacific Futures Network. This essay has in part been based on communications with the artists who I thank. I would also like to thank Dr Glen St John Barclay for his assistance in research.

Coltanski, in conversation with Tamar Garb in Didier Semin, Tamar Garb, Donald Kuspit 'Christian Boltanski', Phaidon, London and New York, 1997, 2001, p. 37.

2 Salvador de Madariaga, 'Morning without Noon', 1974.

3 Christine Chinkin 'The Language of Human Rights Law' in Caroline Turner and Nancy Sever (eds.), 'Witnessing to Silence: Art and Human Rights', Exhibition Catalogue, Drill Hall Gallery and Humanities Research Centre, ANU, 2003, p.13.

4 Simon Wright, 'Out of Print: gordon bennett', Brisbane, Griffith University, 2004, pp. 78-79.

5 Linda Colley, The Guardian quoted http://www,aljazeerah.info/pinion\%20 editorials/2003\%20opinion\%20Editorials/jul... Consulted 2 August 2005.

6 Dadang Christanto [Charles Darwin University, Newsroom, http://www.edu.au/newsroom/stories/2003/april/count/] Consulted 15 January 2005.

7 Robert Cribb, 'The tragedy of 1965-66 in Indonesia', unpublished paper, 2005.

8 'I still remember during December 1972, all my family stayed underground... in the centre of Hanoi. Bombs everywhere ... all women including my grandmother and my mum was praying...' Tran Luong communication with the author 11 August 2005.

$9 \quad$ Nicholas Thomas, 'Possession: Indigenous Art/Colonial Culture', Thames and Hudson, 1999, p. 269, quoted by Simon Wright in unpublished communication, 2005.

10 Ann Robinson, 'John Pule', Arts Foundation of New Zealand, http://www.artsfoundation.org.nz/johnpulke.htm Consulted 29 July 2005.

11 Dadang Christanto [Charles Darwin University, Newsroom, http://www.edu.au/newsroom/stories/2003/april/count/]. Consulted 15 January 2005.

12 Anna Sloan, 'A Divine Comedy of Errors: Political Paintings by Saira Wasim', catalogue, 'Transcendent Contemplation: The Art of Saira Wasim', http://www.sairawasim.com/. Consulted 2 August 2005.

13 Saira Wasim artist statement http://www.sairawasim.com/statement.html Consulted 16 August 2005

$14 \quad$ Alfredo Jaar http://www.insite97.org/artistfinal/jaar. Consulted May 2003.

15 Exhibition Guide 'Wong Hoy Cheong', Panduran Pameran, Kuala Lumpur, 2004.

${ }_{16}$ Laura Murray Cree 'Looking for Enemies' exhibition catalogue, essay Sherman Galleries, 2004, unpaginated 